\title{
The Aristotelian Good Life and Virtue Theory
}

\author{
Jack Smith \\ Graduate Student \\ Philosophy Department \\ University of Illinois-Springfield \\ One William Maxwell Ln \\ Springfield, IL 62703, USA
}

\begin{abstract}
In The Nicomachean Ethics, Aristotle sets forth his concept of the good life, or eudaimonia, which must be distinguished from today's concept of happiness in that it is much more systematized, rigid, and carefully nuanced. While Aristotle's system of ethics appears, prima facie, to be an exhaustive moral guide to the good life, it exhibits certain elitist tendencies and advocates certain elitist doctrines which ultimately impact its validity and soundness, thus rendering his basis for the good life untenable.
\end{abstract}

Keywords: eudaimonia, virtue, contemplation, external goods, misogyny, aristocratic bias, slavery

\section{Introduction}

On the subject of ethics, we cannot ignore Aristotle, who is the first exponent of virtue theory, which is characterversus rule-oriented. He sets forth his theory of the good life in two works, The Nicomachean Ethics and the Eudemian Ethics--the first being the text most often discussed. His concept of the good life, or eudaimonia, is usually termed happiness, or the flourishing life, but it must be distinguished from today's concept of happiness in that it is much more systematized, rigid, and carefully nuanced, reflecting careful precision in both concepts and terms. Even so, I will argue in this paper that while Aristotle's system of ethics appears, prima facie, to be an exhaustive moral guide to the good life, it exhibits certain elitist tendencies and advocates certain elitist doctrines which ultimately impact its validity and soundness, thus rendering his basis for the good life untenable.

\section{The Moral Guide to the Good Life}

\subsection{The Good Life Defined}

As a moral guide to the good life, Aristotle's ethical theory is thorough and complex. In Books I - III of the Nicomachean Ethics (2009), he sets forth much of his theory. He defines the nature of the human good; the nature of virtue and how to acquire it; the necessary conditions related to the agent himself; and the nature of deliberation and choice. The primary audience for this work, according to Bartlett (2008), consists of "'serious' human beings, who as such accept as their starting point or first principle . . the supreme goodness of moral virtue and hence noble actions"; they have come to know virtue not by teaching but by habituation from early childhood on (679). What, then, is the purpose of this work? According to Warne (2006), "Aristotle's concern is to identify the ultimate goal of human beings as a natural kind" (p. 18). To do so, he seeks to know "the function of man" (1097b24). To determine this, he must differentiate the nature of man from that of animal and vegetative life. What separates humans from plants and animals is their reason (1097b32- 1098a3). The function of man, then, "is the activity of soul which follows or implies reason" (1098a8-9). According to Aristotle's naturalism, each thing has in its being an entelechy that pushes it to actualize its potential. To actualize his potential, man must act from reason. When is an action good? It is good when it is "performed in accordance with the appropriate virtue" (1098a15), and virtue requires reason--"correct reason" (1103b32). This being the case, the "human good turns out to be activity of soul exhibiting virtue" (1098a16-17). Virtue, Aristotle stipulates, must not be sporadic in behavior but must govern one's whole life. As he famously puts it, "For one swallow does not make a summer, nor does one day" (1098a19-20). 


\subsection{The Nature of Virtue}

But what exactly is virtue? For Aristotle, there are two kinds of virtue, intellectual and moral; intellectual virtue is displayed in teaching, whereas moral virtue is developed from habit (1103a16-17). It must be emphasized that while a potential for moral virtue is natural, virtue itself does not come naturally, "for nothing that exists by nature can form a habit contrary to its nature" (1103a27-28; 1103a20-21). It is also important to understand what Aristotle means by "habit." According to Warne (2006), we must not confuse the word "habit" with an action performed "without thinking"; virtues are instead "habituated states of character, but are not themselves habits" (p. 37, 38).

Indeed, for Aristotle, we must think of having achieved various moral virtues as "states of character," for which we can be "praised or blamed" $(1105 \mathrm{~b} 25 ; 1106 \mathrm{a} 1)$, and such praise or blame applies to what a man has become by force of habit since an early age. A man who acts unjustly or a man who acts with self-indulgence has, according to Aristotle, chosen to act in this way (1114a11-13). As to men who practice these two vices, since they have become men of this type, "it's not possible for them not to be so" (1114a20-23). It is not easy to be good, he notes (1109a24), yet Aristotle does hold that virtuous acts must be pleasant and enjoyable "since no one would call a man just who did not enjoy acting justly, nor any man liberal who did not enjoy liberal actions, and similarly in all other cases" (1099a19). This ethical position is radically different from Kant's deontological one, which excludes emotion altogether when determining the moral worth of an action. For Aristotle's character-based ethics, the agent's wanting to be just or liberal reflects an habitualized ethical orientation toward a given virtue.

Aristotle's virtue ethics is mostly known for the golden mean, which applies to passions as well as actions (1106b16-17). Moral virtue is the "mean" between "defect" and "excess," both of which are vice (1104a121104a26). Aristotle also refers to this mean as the "intermediate" position, by which he means "that which is equidistant from each of the extremes" (1106a30). This intermediate position will vary from individual to individual, and from circumstance to circumstance, though the principle itself is "one and the same for all" (1106a30-31). Stumpf and Fieser (2003) sum up the nature of this golden mean in terms of habitualized behaviors: "Moral virtue . . . consists of cultivating habits which will spontaneously incline us to take the middle course of action--or simply avoid bad conduct in the case of actions like theft and murder" (94). It should be noted that not every passion or action is subject to the Aristotelian mean. Some actions are wrong period, such as "adultery, theft, and murder" (1107a11). It should also be noted that Aristotle's moral virtues do not always apply to morality as we moderns normally conceive of it. For instance, in regards to "truth," Aristotle states that "boastfulness" is the excess, "mock modesty" the deficit, and "truthfulness" the mean. If one wants to be "amusing," displaying "ready wit," he will avoid "buffoonery," the product of excess, as well as "boorishness," the product of deficiency (1108a20-27). What part does a self-regarding ethic such as "ready wit" play in a moral system, which we normally think of as other-regarding? Wilkes (1978) states that the Greeks did not distinguish between these two: "The essential thing to realize is that Aristotle--and Plato--wrote in a time when the distinction between the moral (other-regarding) and prudential (self-regarding) virtues had not yet been framed" (p. 569). The focus, for them, was the good life, with virtue in its various forms relating to the function of man as a rational creature. Both other-regarding and self-regarding virtues count as long as they meet Aristotle's various criteria for virtue.

One criterion has to do with the role of the agent himself. For an action to be virtuous, he or she must meet three non-negotiable conditions: 1) act out of knowledge, 2) choose to do what is virtuous because it is virtuous; and 3) act from "a firm and unchangeable character" (1105a31-34). Audi (1995) terms these conditions Aristotle's "character requirement: virtues are elements of character; those elements are 'firm and unchanging'; hence, an action from virtue must be from an element with the appropriate entrenchment and stability" (p. 451). Let us now focus on the second condition--the importance of choice. Choice is integral to Aristotle's ethics, "for it is thought to be most closely bound up with virtue, and to discriminate characters better than actions do" (1111b5-6). But we must not conflate voluntary action with choice, states Aristotle, for children as well as animals are fully capable of voluntary action but not choice (1111b7-9), which is based on reason. Aristotle takes pains to distinguish choice from appetite, wish, and opinion. Let's consider the first two of these. As to appetite, the difference between the incontinent and the continent man is that appetite, not choice, drives the former while choice, not appetite, drives the latter (1111b13-15). Wish pertains to the end, "choice to the means" (1111b27-28). The object of wish is the "apparent good" as each man individually conceives of this $(1113 \mathrm{a} 16,22)$. 
On this point, we must keep in mind, states Aristotle, that "each state of character has its own ideas of the noble and the pleasant, and perhaps the good man differs from others mostly by seeing the truth in each class of things, being as it were the norm and measure of them" (1113a31-34). According to Brown in his notes to The Nicomachean Ethics (2009), this "language recalls Protagoras' 'man is the measure' dictim . . . but Aristotle corrects Plato by making the good man the measure" (p. 221).

Choice, which governs means to ends, follows deliberation and requires reason and thought. What do we deliberate about prior to making a choice? "We deliberate about things that are in our power and can be done" (1112a31). Vice and virtue are both in our power (1113b8-9), and thus it is up to us whether or not we become virtuous or vicious persons (1113b13-14). Wickedness, Aristotle points out, "is voluntary," or "we would have to deny that man is a moving principle or begetter of his actions, as of children" (1113b16-18).

Moral virtue, then, is based on reason, habit, and choice. It reflects man as a rational creature, and it is essential for the good life, the flourishing one. But a key question remains: While moral virtue is essential to the good life, is it sufficient? Aristotle is aware, naturally, of other things besides virtue. There are a number of so-called external goods, including good birth, money, and friends. What part do they play in the eudaimon life?

\section{External Goods}

Clearly, Aristotle relates the possession of external goods to virtuous acts themselves: "for it is impossible, or not easy, to do noble acts without the proper equipment" (1099a32-33). But what about happiness? What if we lack certain external goods? Indeed, Aristotle does note that "there are some things the lack of which takes the lustre from happiness--good birth, goodly children, beauty..." (1099b2-4). Yet Aristotle's description of the role of external goods suggests, in fine, an ambiguous position on this matter when he states that "happiness seems to need this sort of prosperity in addition; for which reason some identify happiness with good fortune, though others identify it with virtue (italics mine)" (1099b8-10). Similarly, Aristotle follows this statement up with one regarding "the remaining goods" beyond virtuous acts: "some must necessarily pre-exist as conditions of happiness, and others are naturally co-operative and useful as instruments" (1099b27-29). These summative remarks leave us with a puzzle on exactly how external goods relate to virtue, and to happiness. Are the relations between these elements variable? Is there a particular principle that governs these relations?

Scholars have tried to solve this puzzle. For instance, Cooper (1985) sees the possession of external goods as related to being virtuous. He states, "The virtuous person will generally and regularly get these goods as an immediate consequence of his being virtuous, so that they should not be counted as goods that he needs as supplements to virtue if he is to be happy" (p. 195). Warne (2006) responds, "On this reading, virtuous activity is what is responsible for the correct management of external goods into the eudaimon life" (p. 31). Roche (2014) holds that "an external good may promote a person's happiness only if that person is a virtuous person" (p. 40). In spite of his ambiguity on the role of external goods, Aristotle has presented an ethical theory that is, on the whole, clear, thorough, and nuanced. It is tightly argued in terms of defining the nature of the good life, in stipulating what is and what is not virtue, and in identifying the means of acquiring it. How does Aristotle's concept of virtue compare to our modern conception of happiness? Kraut (1979) finds similarities, the difference being that Aristotle's is "objective and stringent," while ours is "subjective and flexible" (p. 167). Similarly, Kekes (1982) holds that Aristotle, along with Plato and Christian moralists, has standards of happiness that "are objective both ontologically and epistemologically" (p. 369). One cannot imagine this assessment of today's feelgood kind of happiness that ordinary people embrace.

\section{The Contemplative Life}

Especially, one cannot imagine any proponent of the happiness movement under the aegis of Martin Seligman, positive psychology guru at the University of Pennsylvania, emphasizing the contemplative life, as Aristotle does in Book X of the Nicomachean Ethics (2009). This contemplative life Aristotle likens to divinity, or pure reason. One can connect this with the very nature of man as a rational creature, actualizing his fullest potential. Yet this final book in his major work on ethics seems at odds with the rest of the book and has garnered much scholarly attention.

For Wilkes (1978), the conflict cannot be resolved. But we can dispute Aristotle's premises regarding the superiority of the contemplative life as well as his sharp distinction between philosophic thinking and practical reasoning (p. 566-67). 
In disputing these critical premises, it will then follow that "neither life is, as such, better than the other" (p. 570). On the other hand, Kraut (1991), adhering to a reading of the Aristotelian ethic, as is, holds that, for Aristotle, if one chooses the philosophic life, with favorable circumstances, he "attains perfect happiness"; if he chooses to live a life of "virtuous practical activity," he chooses to "be happy in a secondary way" (p. 5). Lawrence (1993), too, holds that, for Aristotle, the life of contemplation is the happiest of all, while the life focused on moral character is viewed as secondary (p. 2). For further clarification, Lawrence adds that Aristotle does not mean "that the happiest human life is one where we value only one thing, theoretical activity" (p. 14). What he does mean is that "the happiest human life is one whose circumstances are such as to allow us to engage in contemplation as much as a human ever can" (p. 14). Bush (2008), on the other hand, finds in Aristotle, as does Wilkes, a radical, irresolvable split--one based on crucial ontological differences between the human and divine. Speaking of the contemplative life, he states: "He does not see it, properly speaking, as a human good. Humans, or at least a select few of them, can obtain the divine good of contemplation, but the human good is the activity that is characteristically human: morally virtuous activity. Contemplation is the characteristically divine good, and so it does not qualify as the characteristically human good" (p. 51).

If contemplation is not "the characteristically human good," those who give their life to contemplation are behaving as though they are divine. Russell (1945) also comments on the divine nature of this kind of contemplation, stating that "It is open to man to increase the element of the divine in his nature, and to do so is the highest value. But if he succeeded completely, he would have ceased to exist as a separate person" (p. 172). Since Aristotle seems to privilege the select few who can engage in a life given to such intellectual contemplation, clearly he seems to embrace radical intellectual elitism. Yet this kind of elitism is not, I argue, pernicious unless we divorce reason from virtue, as Kant warns of the reason unattended by the good will. One can certainly commit oneself to the contemplative life versus being a "social worker" in the polis--the two options Wilkes (1978) suggests--without excluding the other virtues (p. 570). One's virtuous life would simply be given exclusively to intellectual contemplation--focusing on Mill's higher pleasures, if one wants to think of it that way-instead of social and political involvement.

It is not Aristotle's emphasis on the contemplative life, as such, that damages his ethical system; but we do have to realize that a life given entirely to intellectual pursuit is not open to everyone, and therein lies Aristotle's aristocratic bias, which we will consider soon. The argument of this paper is that while Aristotle's ethics appear to be a sound moral guide to the pursuit of the good life, there are certain elitist tendencies that call into question the rock-bottom soundness of his ethics. These include his misogyny, his aristocratic sympathies, and his support of natural slavery. We will turn to each of these issues in the following sections of this paper.

\section{Misogyny}

We should begin with some telltale misogyny in The Nicomachean Ethics (2009). Note how, for instance, Aristotle faults the man who is "defective in respect of resistance," the man who is "soft and effeminate" (1150b2-3). We moderns cannot help but see in this language a slur on women, especially as Aristotle opposes these character traits to "the man of endurance" (1150a34). He becomes explicit when he speaks of "that which distinguishes the female sex from the male" (1150b14-15), meaning by this a natural "softness" (1150b13). According to Miller (2017), Aristotle "is unconvincing to modern readers when he alleges (without substantiation) that, although women have a deliberative faculty, it is 'without authority' . . . so that females require male supervision." If one views this as gender elitism, I think this is a fitting term. We see gender elitism also in Aristotle's comparison of the relationship of father to son with man and wife--and, on the political level, with ruler to subject (1158b13). He views these relationships as a matter of "inequality between the parties" (1158b12), which must be respected, one assumes, since such inequalities are natural. Note his bias toward women in government: "Sometimes, however, women rule, because they are heiresses; so their rule is not in virtue of excellence but due to wealth and power, as in oligarchies" (1161a1-3).

\section{Aristocratic Bias}

Beyond gender prejudice, Aristotle is also elitist in his aristocratic bias. The magnificent man he comments on in The Nicomachean Ethics (2009) is one who can give liberally to the polis, but Aristotle holds him up too much--at least to most moderns' taste--as a model of the good citizen, whose giving "surpasses liberality in scale" (1122a21-22). Aristotle's approval of the magnificent man is certainly in keeping, as he emphasizes, with his concept of virtue as related fundamentally to the agent: 
"It is what is fitting, then, in relation to the agent, and to the circumstances and the object" (1122a25-26). The magnificent man is, above all, a virtuous man, for he "will spend such sums for the sake of the noble; for this is common to the virtues" (1122b6-7). The poor man is not able to manage such liberality and thus "cannot be magnificent"; the poor man who tries to do so is but a "fool" (1122b27-29). Aristotle's aristocratic bias becomes abundantly clear in this passage: "But great expenditure is becoming to those who have suitable means to start with, acquired by their own efforts or from ancestors or connections"; furthermore, this standard of "becoming" applies also "to people of high birth or reputation, and so on, for all these things bring with them greatness and prestige" (1122b29-33). The problem here is that while we can appreciate the magnificent man's great liberality, including his noble motive, Aristotle's placing him on a pedestal seems obvious elitism. Perhaps the poor man could be "magnificent," but in a different way. Even if we grant that he's a "fool" if he gives way beyond his means--he would surely be profligate in Aristotle's terms--perhaps his heart, as they say, is in the right place. And why celebrate the man who has so much to give and not celebrate liberality period? And on a similar elitist note, only consider Aristotle's concept of friendships "based on superiority" (1163a24) in Book VIII, chapter 14, of The Nicomachean Ethics (2009). He has already prepared us for a reception of "superiority" in terms of gender; in VIII.13, he turns to social class, marking some men as superior, others as inferior (1162b4). I will repeat here that one cannot help but view a life given exclusively to intellectual pursuits--in spite of the value of higher pleasures in Mill's sense--in the context of Aristotle's classism.

\section{The Polis}

Let us now turn to Aristotle's position on government. First, consider his restrictive definition of "citizen." In Book III of the Politics (2009), Aristotle makes it clear that in addition to aliens and slaves, ordinary workers must be denied citizenship "in the best form of city"--that is, his ideal government--since citizenship status "can only be achieved by those who are free from the necessary tasks of life" (1278a 8,12-13). Mechanics and laborers, because of the nature of their menial work, are not suitable for citizenship. As to the best types of government, Aristotle views these as monarchy, aristocracy, and constitutional government--in that order. What he does not endorse is democracy, rule by the masses, which he considers a deviant form of constitutional government.

Drawing from the Politics (2009), Aristotle associates monarchy, or kingship, with aristocracy: "Kingship . . . may be classified with aristocracy, since it is based on merit" (1310b31-32). Moreover, "Kingships have grown for the purpose of helping the better classes against the populace"; indeed, states Aristotle, "it is from these classes that kings have been drawn; and the basis of their position has been their own pre-eminence or the preeminence of their family, in character and conduct" (1310a50-54). We can certainly detect Aristotle's elitist position in his defense of the origins of kingship and in his favoring the "better classes" over the "populace." Constitutional government, though a drift to democracy, privileges the affluent middle class. For Aristotle, "the middle classes enjoy a greater security themselves than any other class. They do not, like the poor, desire the goods of others ..." (1295b34-36).

Democracies without middle class rule, ruled instead by the poor, are doomed: "trouble ensues, and they are speedily ruined" (1296a18-21). Aristotle conceives of democracy as mob-rule. Note what he says in The Nicomachean Ethics (2009): "Democracy is found chiefly in masterless dwellings (for here everyone is on an equality), and in those in which the ruler is weak and everyone has licence to do as he pleases" (1161a6-8). Aristotle also refers to the common man as "the common stock" (1163b8). Turning once again to the Politics (2009), Aristotle states that democracy is typified by two features, "the sovereignty of the majority" and "the liberty of individuals" (1310a36-37). In a democracy, justice is based on "the will of the masses as sovereign," with liberty amounting to "“doing what one likes"” (1310a38-39). In Aristotle's judgment of unrestrained liberty, one can detect a similar judgment on the part of Edmund Burke regarding the unrestrained liberty of those who carried on the French Revolution.

What we take away from Aristotle's political system in the Politics (2009) is that not everyone deserves citizenship because even though "they are necessary to the city's existence" (1277b45), their social status (as slaves) or the nature of their menial work (as laborers and mechanics) keeps them--properly, to Aristotle's mind, we should add--from participating in the political life of the city state. Aristotle's sense of privilege extends to the middle class, for they can, he believes, participate fully in a democratic form of government where they can serve on the assembly, juries, etc. He trusts the middle class as being more "ready to listen to reason," while the poor "find it hard to follow the lead of reason" (1295a48, 50-51). 
Clearly this is evidence of Aristotle's classism, which excludes the poor from participating in his ideal city state. Russell (1945) identifies the purpose of the State, as Aristotle conceives it: "The aim of the State, in his view, is to produce cultured gentlemen--men who combine the aristocratic mentality with love of learning and the arts" (p. 194). For Aristotle, the lower classes do not fit such a model, nor can they have a share in it.

\section{Slavery}

If Aristotle's aristocratic bias is troubling, his endorsement of slavery is much more so. His concept of natural slavery calls into question the moral integrity of his entire ethical system--at least for moderns, who do make distinctions between self-regarding and other-regarding virtues (unless we're speaking of ethical egoists). To begin with, slavery is one of the constituent elements of the household, as Aristotle establishes in the Politics (2009). "A complete household consists of slaves and freemen" (1253b 6-7). Furthermore, households must include property: "Property is part of the household and the art of acquiring property is part of household management, for it is impossible to live well, or indeed at all, unless the necessary conditions are present" (1253b23-26). It is impossible to live well, then, without slaves since they are part of this household property. And what is property? That which has instrumental value only: "Each article of property is thus an instrument for the purpose of life, property in general is a quantity of such instruments, the slave is an animate article of property..." (1253b33-36). As mere property, slaves are certainly not to be given citizenship, even though they, like the free-born, "are necessary to the city's existence" (1277b44-45).

The slave, as Aristotle sees it, is a lesser being. One element deciding the slave's fate has to do with intelligence versus bodily power, the former being naturally the ruling element, the latter, suited to physical labor, being naturally the ruled. These conditions assumed to be true, "master and slave have accordingly a common interest" (1252a 34-39). Another element deciding the slave's fate is his capability of becoming property and being "destitute" of reason in terms of rational decision-making: "Someone is thus a slave by nature if he is capable of becoming the property of another," and, says Aristotle, "for this reason does actually become another's property" (1254b22-24).

Given these basic premises, Aristotle holds that slavery is natural and just. As he states in the Politics (2009), "It is thus clear that, just as some are by nature free, so others are by nature slaves, and for these latter the condition of slavery is both beneficial and just" (1254b39-41). Just as the rational part of the soul rules over the irrational, it is natural for the freeman to rule over the slave (1260a11-12). According to Miller (2017), "Aristotle thinks that this form of rule [despotic rule] is justified in the case of natural slaves who (he asserts without evidence) lack a deliberative faculty and thus need a natural master to direct them." Yet Miller also notes that for Aristotle "despotic rule is still primarily for the sake of the master and only incidentally for the slave." Oddly, in The Nicomachean Ethics, Aristotle refers to the master's rule over his slaves as "tyranny" (1160b29), but we must note, at the same time, that it is not slavery itself but the manner of treatment of the slaves that concerns him: "Now this seems to be a correct form of government, but the Persian type is perverted..." (1160b30-32). This raises an ethical question: where is the line to be drawn on the treatment of one's human property? We might see a parallel here between those who militate against mistreatment of animals in factory farming operations but not factory farming operations, per se. To alleviate suffering, animal welfarists argue for larger confinement units; animal rightists argue for no such units at all. Aristotle's position on slavery seems to smack of the welfare argument, certainly not the rights one.

Indeed, Aristotle's support of natural slavery reveals his dehumanization of a whole class of people. Copleston (1944) faults Aristotle for his "tendency to regard the 'slave-nature' as something almost less than human" (Vol I, 353). As a slave, one cannot claim autonomy in the least, for, as Aristotle says in the Politics (2009), "while the master is merely the master of the slave, and does not belong to him, the slave is not only the slave of his master, he also belongs entirely to him" (1254a12-14). If viewed in strictly Kantian terms (regardless of Kant's own position on slavery), Aristotle's position certainly violates the second version of the categorical imperative. Harris (2012) states: "Slavery by definition does not respect the autonomy of the slave, and it does not allow for a society in which all people are treated as ends-in-themselves" (p. 6). Speaking of both his politics and his belief in slavery, Aristotle scholar Martha C. Nussbaum (2011) finds him considerably flawed. "He was happy with a system like that of the Athens of his day, in which only free adult nonimmigrant males were citizens and in which slavery was practiced. ... He seemed to lack the basic idea of human equality, of a worth all humans share across differences of gender, class, and ethnicity" (p. 128). 


\section{Ethical Relativism}

Given the fact that the Greek city state was culturally different from modern political units, one could argue that we must situate ourselves in Aristotle's own time, not contextualize his ethics according to our own, but this is a relativist position I do not accept, neither latitudinally (in our own time) nor longitudinally (in an earlier time in history). I take the position of James Rachels (1993), who argues that it makes sense "to condemn some practices, such as slavery and anti-Semitism, wherever they exist." And I might add, whenever they have existed. I also take the position of Mary Midgley (1981), who, in "Trying Out One's New Sword," criticizes cultural relativism as leading to "moral isolationism" (p. 69-75). I think it behooves us to judge Aristotle's benighted view of slavery just as we should judge the benighted view of slavery in the Americas a few thousand years later-or the benighted view of Europeans in their attitudes toward the indigenous peoples of the Americas.

\section{Conclusions}

In summary, Aristotle's ethical system in terms of the good life, while it is thorough and complex, nonetheless is flawed due to its elitism with respect to gender, social class, and the basic rights of all humans. The good life should be for the many, not for the few. While we must read Aristotle in terms of his social and political contexts, we need not embrace his values, and we will not if we are moral objectivists instead of moral relativists. Aristotle's version of virtue ethics comes up short when virtue allows discrimination and the treatment of other humans as mere things, and not as ends in themselves.

\section{References}

Aristotle. (2009). The Nicomachean Ethics. (David Ross, Trans.). Introduction and Notes by Lesley Brown. New York: Oxford University Press.

Aristotle. (2009). Politics. (Ernest Barker, Trans.). Introduction and Notes by R.F. Stalley. New York: Oxford University Press.

Audi, R. (1995). Acting From Virtue. Mind, 104(415), new series, 449-471. Retrieved from http://www.jstor. org.library.ncmissouri.edu:8080/stable/2254637

Bartlett, R. (2008). Aristotle's Introduction to the Problem of Happiness: On Book I of the "Nicomachean Ethics". American Journal of Political Science, 52(3), 677-687. Retrieved from http://www.jstor.org.library.ncmissouri.edu:8080/stable/25193840

Bush, S. (2008). Divine and Human Happiness in "Nicomachean Ethics". The Philosophical Review, 117(1), 49-75. Retrieved from http://www.jstor.org.library.ncmissouri.edu:8080/stable/41441846

Cooper, J. (1985). Aristotle on the Goods of Fortune. The Philosophical Review, 94(2), 173-196. doi:10.2307/2185427

Copleston, S.J. (1944). A History of Philosophy. Book One. New York: Doubleday, 1944.

Harris, Mark E. (2012). Examining Moral Necessity in the Kantian Categorical Imperative. The Catalyst: Vol. 2: Iss.1, Article 2. DOI: 10.18785/cat.0201.02. Retrieved from http://aquila.usm.edu/sout hernmisscatalyst/vol2/iss1/2

Kekes, J. (1982). Happiness. Mind, 91(363), new series, 358-376. Retrieved from http://www.jsto r.org.l ibrary.ncm issouri.edu:8080/stable/2253226

Kraut, R. (1991). Aristotle on the Human Good. Princeton, NJ: Princeton University Press.

Kraut, R. (1979). Two Conceptions of Happiness. The Philosophical Review, 88(2), 167-197. doi:10.230 7/218 4505

Lawrence, G. (1993). Aristotle and the Ideal Life. The Philosophical Review, 102(1), 1-34. doi:10.2307/2185651

Midgley, Mary. (1981). Trying Out One's New Sword. In Heart and Mind: The Varieties of Moral Experience (69-75). London, England: The Harvester Press.

Miller, Fred. (2017). Aristotle's Political Theory. In E. Zalta (Ed.), Stanford Encyclopedia of Philosophy. Retrieved from https://plato.stanford.edu/

Nussbaum, Martha C. (2011). Creating Capabilities: The Human Development Approach. Cambridge, MA: Harvard University Press.

Rachels, James (1993). The Elements of Moral Philosophy. Second Edition. New York:McGraw-Hill.

Roche, T.D. (2014). Happiness and the External Goods. In Ronald Polansky (Ed.), The Cambridge Companion to Aristotle's Nicomachean Ethics (34-63). New York: Cambridge University Press.

Russell, Bertrand. (1945). The History of Western Philosophy. New York: Simon \&Schuster.

Stumpf, Samuel Enoch, \& Fieser, James. (2003). Socrates to Sartre and Beyond: A History of Philosophy. Seventh Edition. New York: McGraw-Hill.

Warne, Christopher. (2006). Aristotle's Nicomachean Ethics: Reader's Guide. New York: Continuum.

Wilkes, K. (1978). The Good Man and the Good for Man in Aristotle's Ethics. Mind, 87(348), new series, 553-571. Retrieved from http://www.jstor.org.library.ncmissouri.edu:8080/stable/2253690 